\title{
China: Inward and Outward Foreign Direct Investment"
}

\author{
Karl P. Sauvant
}

\begin{abstract}
China has become a major player in the world foreign direct investment market. After emerging, during the 1980s, from its isolation and beginning its integration into the world economy, China rapidly became a major host country for foreign direct investment (FDI). This article provides a brief review of China's inward and outward direct investment, as well as its policy context and challenges that China is facing.
\end{abstract}

Key words: Foreign direct investment, development policy, China

\section{Inward and Outward FDI}

China has become a major player in the world foreign direct investment market. After emerging, during the $1980 \mathrm{~s}$, from its isolation and beginning its integration into the world economy, China rapidly became a major host country for foreign direct investment (FDI). ${ }^{\dagger}$ Foreign firms were attracted by both the country's growing domestic market and its potential as an export platform.

After years of isolation and poor economic performance, China's economy began to open up in the 1980s, including for FDI. While foreign firms were attracted by the Chinese market, the government initially wanted foreign affiliates to be export-oriented. Firms were attracted by the availability of skills at low wages and an improving infrastructure; in addition, the regulatory framework for FDI improved over time. And, of course, firms wanted to establish a foothold in the country's huge market. This strategy proved successful, both for the government and multinational enterprises (MNEs): over half of China's exports originate today from foreign affiliates located in the country, and this share has, if anything, grown, while total exports rose from US\$ 149 billion in 1995 to US\$ 1.2 trillion in 2009. China became the new "workshop of the world".

Over time, the Government of China opened its domestic market to sales by foreign affiliates located in the country. This went hand-in-hand with the country's moving toward becoming a market economy, and growing rapidly; in fact, the country has seen one of the most astonishing growth performances over a sustained period of time. With it grew the purchasing power of Chinese consumers and firms, who were previously starved of goods and services of all kinds, ranging from consumer goods to capital equipment. FDI inflows - a trickle until the early 1990s - soon rose substantially, reaching \$108 billion in 2009 - a year during which world FDI flows had declined by some 50 percent in the wake of the financial crisis and recession. Sales of foreign affiliates in China grew from US\$10 billion in 1990 to US\$ 545 billion in 2009. Since 1994, China has been the most important host country among developing countries and economies in transition, testifying to the country's attractiveness in light of the principal FDI determinants, including size of market, economic growth, availability of skills and good infrastructure, and an enabling regulatory framework.

\footnotetext{
* Adapted from the Preface to the Proceedings of the Conference on Research and Development: Transnational Corporations in China, which took place in Xi' an, China, August 26-28, 2010. Published by Denfar Transnational Development online in 2010 at www.tnc-online.net/page/cp2010/index.php.

$\dagger$ For a most recent overview of foreign direct investment and China, see Ken Davies, "Outward FDI from China and its policy context", Columbia FDI Profiles, August 19, 2010, and Ken Davies, "Inward FDI in China and its policy context", Columbia FDI Profiles, August 19, 2010.
} 
This performance benefited from the gradual improvement of the country's regulatory framework for FDI. It also benefited from vigorous efforts of China's investment promotion agencies at all levels of the country. At the same time, the government also has seen to it that the country not only attracts more investment, but also that the investment it attracts makes as much of a contribution to economic development as possible, including by strengthening China's science and technology infrastructure. The result has been that both the country and MNEs have benefited from China's opening up to FDI.

In this environment, Chinese firms themselves prospered and became more competitive. They rapidly approached the capacity to invest abroad, having assembled at least some of the firm-specific advantages that make such investment possible and profitable. Beginning in 2000, they were encouraged to expand abroad through the government's "Go Global" policy that slowly liberalized the regulatory framework for outward FDI and, eventually, introduced encouraging elements. ${ }^{*}$ As a result, outward FDI from China grew from a trickle in the early 1990s to over $\$ 50$ billion in 2009, making the country that year the world's fifth largest home country for FDI (not counting Hong Kong). (For comparison: world FDI flows during the first half of the 1980s averaged $\$ 50$ billion a year.) Chinese firms are expanding abroad in all sectors and in all continents. If the country's currency should be revalued, this would further facilitate its firms to expand abroad. Acquiring a portfolio of locational assets, in turn, will further strengthen the international competitiveness of Chinese firms.

\section{Challenges}

Thus, as regards both inward FDI and outward FDI, China has become a major player in the world FDI market. Being newcomers in this market poses of course a number of challenges, for firms and for governments.

On the inward FDI side, China's government wants to ensure that the country benefits as much as possible from the investment it gets. After all, from the government's perspective, FDI is a tool that can help advance the country's economic growth and development. At the same time, the government needs to be careful to find the right balance between seeking to increase the benefits it can extract from foreign firms, on the one hand, and discouraging these firms from establishing themselves in China (or to staying there) - you do not want to kill the goose that lays the golden eggs. The government also faces the challenge of encouraging the flow of investment to the central and western provinces that, so far, have received only a very limited amount of FDI. Foreign investors need to keep an eye on the opportunities that arise in other parts of China. More importantly, they need to recognize that, as good corporate citizens, they need to contribute to China's economic, social and environmental development in the context of good governance mechanisms, and on the basis of commercially viable ventures.

On the outward FDI side, Chinese MNEs face the challenge - like MNEs from other countries - of overcoming the liability of foreignness, a challenge that is particularly great for firms from China, as they are newcomers in the world FDI market and hence have little experience with operating in different, often sophisticated and always challenging environments. ${ }^{\dagger}$ Becoming successful and becoming good corporate citizens requires companies to become attuned to the economic, social, environmental, and political practices of host countries. The government of China can help in this respect, including by promulgating a code of conduct for all their firms operating abroad and seeing to it that it is being observed and, beyond that, by encouraging their MNEs to comply with international standards of conduct. Host countries to

\footnotetext{
* See Qiuzhi Xue and Bingjie Han, "The role of government policies in promoting outward foreign direct investment from emerging markets: China's experience”, in Karl P. Sauvant and Geraldine McAllister, with Wolfgang A. Maschek, eds., Foreign Direct Investment from Emerging Markets: The Challenges Ahead (New York: Palgrave Macmillan, 2010), pp. $305-323$. $\dagger$ See Karl P. Sauvant, ed., Investing in the United States: Is the US Ready for FDI from China? (Cheltenham: Edward Elgar, 2010).
} 
Chinese FDI, for their part, need to accept that Chinese investment, like investment by firms from other countries, can make a contribution to their economic growth and development and, for that reason, should not discriminate against it.

Finally, what cuts across both inward and outward FDI is that, increasingly, the issue for governments is not only to get more FDI, but also to get better FDI, i.e., the quality of such investment matters more and more, not only the quantity. "Quality" is of course difficult to define. I consider FDI that contributes as much as possible to a country's economic, social and environmental development, and takes place in the context of governance mechanisms that allow a fair sharing of the benefits of such investment between firms and host countries, as high quality, or sustainable, FDI. Naturally, this concept requires further elaboration and a discussion of what the implications are for policy makers and firms, and this is a process that is just beginning. China's new role in the world FDI market not only gives an impetus toward examining this issue, but also puts the country in a position to take leadership in it.

\title{
3. Conclusions
}

These are just a few issues that Chinese firms, the government of China, other governments and FDI stakeholders in general face in light of China having become a major player in the world foreign direct investment market. There are many others, and a few of them are being explored in this issue of Transnational Corporations Review containing articles by predominantly Chinese scholars. Naturally, it is work in progress -- not only because various issues are being examined in different degrees of depth, but also because there are many others that need investigation, especially with policy implications in mind.

\section{References}

Davies, Ken (2010), "Outward and Inward FDI from China and its policy context", Transnational Corporations Review, Volume 2, Number 4, December 2010.

Sauvant, Karl, ed. (2010), Investing in the United States: Is the US Ready for FDI from China? Cheltenham: Edward Elgar, 2010.

Xue, Qiuzhi and Bingjie Han (2010), "The role of government policies in promoting outward foreign direct investment from emerging markets: China's experience", in Karl P. Sauvant and Geraldine McAllister, with Wolfgang A. Maschek, eds., Foreign Direct Investment from Emerging Markets: The Challenges Ahead (New York: Palgrave Macmillan, 2010), pp. 305-323

\begin{abstract}
About the Author
Karl P. Sauvant, Ph.D. is the Founding Executive Director of the Vale Columbia Center on Sustainable International Investment; Senior Research Scholar and Lecturer in Law at Columbia Law School; Co-Director, Millennium Cities Initiative; Fellow of the Academy of International Business and Honorary Fellow, European International Business Academy; Senior Advisor, Investment Advisory Committee, China International Investment Council (formerly the China Federation of Investment Promotion Agencies); and Member, International Advisory Council, International Center for Corporate Accountability, Baruch College, CUNY. He is also Guest Professor at Nankai University, China.
\end{abstract}

\section{Contact Information}

Karl P. Sauvant, Ph.D, Executive Director, Vale Columbia Center on Sustainable International Investment Columbia Law School - Earth Institute, Columbia University, 435 West 116th Street, Rm. JGH 638 New York, NY 10027, Tel: (212) 854-0689, Fax: (212)854-7946, Email: karlsauvant@gmail.com. 